\title{
II. 血液
}

\section{1. 貧血患者の診断と治療}

\section{東京女子医科大学血液内科溝口等口秀昭}

Key words : 貧血の診断, 貧血の治療, 網赤血球, MCV

貧血患者の診断の進め方と, 貧血の治療は頻度 の多い鉄欠乏性負血の治療と難治とされる再生不 良性負血の治療を中心に述べることにする。

\section{1. 賓血の診断}

貧血の自他覚所見から貧血を疑うきっかけとな るが, 最近は健康診断で貧血を指摘されて来院す ることも多くなってきている.

\section{1）貧血とは}

負血とは末梢血のへモグロビン濃度が正常以下 に低下した状態である.したがって，成人男性で は $14 \mathrm{~g} / \mathrm{d} 1$ 末満, 成人女性では $12 \mathrm{~g} / \mathrm{d} 1$ 末満の時に貧 血と考え，成因の検查を進める.

\section{2）賽血の成因による分類}

赤血球の産生と崩壊のバランスが崩れた時に唄 血が起こる.つまり，(1)赤血球産生の低下，(2)赤 血球破壊の六進のいずれが起こっても筫血とな る. その他, (3)出血, (4)脾腫があっても赤血球が 脾に貯留し貧血になる（表 1 ）.

3）賓血の成因の検査と進め方

貧血を鑑別する上で注目すべき検查結果は平均 赤血球容積 $(\mathrm{MCV})$ と網赤血球数である.

(1) $\mathbf{M C V}$

まず, MCVの多寡によって, 小球性貧血, 大球 性貧血, 正球性貧血に分けそれらから成因の診断 を進める。

(1) 小球性實血 (MCV $\leqq 80 \mathrm{f})$

MCVの低下を示す小球性貧血はへモグロビン
表 1. 貧血の成因による分類

I. 赤血球産生の低下

1. エリスロポエチン産生の低下

腎性貧血, 内分泌異常による貿血, 感染·炎症· 腫湯による貧血

2. 血液幹細胞の異常

再生不良性賓血, 赤芽球疼, 急性白血病, 腫瑒 の骨骮迶浸潤, 骨髄異形成症候群 (不応性貧血な ぞ)

3. 赤芽球の成熟障害

(1) DNA合成障害（巨赤芽球性貧血 $\rightarrow$ 大球性 貣血), 葉酸・ビタミン $\mathrm{B}_{12}$ 欠乏, 抗白血病 薬投与, オロチン酸尿症, 骨髄異形成症候 群 (不応性貧血など)

(2) ヘモグロビン合成障害 (小球性低色素性督 血), 入厶合成の異常 (鉄欠乏性貧血, 鉄芽 球性貧血, 先天性無トランスフェリン血症, 感染・炎症・腫瘍による筫血), グロビン合 成の異常 (サラセミア, Hbレポア)

II. 赤血球の破壊方進=溶血性唄血

1. 赤血球自身の異常による場合

遺伝性球状赤血球症, 遺伝性棈円赤血球症, 発 作性夜間血色素尿症, 解糖系酵素異常症, 異常 ヘモグロビン症など

2. 赤血球外に異常のある場合

自己免疫性溶血性貧血, 細血管異常性溶血性貧 血など

III. 出 血

IV. 赤血球の分布異常

脾腫を伴う疾患（Banti症候群など）

合成障害による貧血である(表 1 と 2 )。このうち 大半は鉄欠乏性筫血であり，それと他の筫血との 鑑別が大切である。その鑑別診断上大切な検査は 
表 2. 赤血球恒数による筫血の分類

\begin{tabular}{|c|c|c|}
\hline $\begin{array}{c}\text { I. 小球性低色素性筫血 } \\
\text { MCV } 800 \mathrm{f}, \\
\text { MCHC } \leqq 30 \%)\end{array}$ & $\begin{array}{l}\text { II. 正球性正色素性算血 } \\
(\mathrm{MCV}=81 \sim 100 \mathrm{f} \\
\mathrm{MCHC}=31 \sim 35 \%)\end{array}$ & $\begin{array}{l}\text { III. 大球性正色素性顊血 } \\
(\mathrm{MCV} \geqq 1011 \mathrm{f} \\
\mathrm{MCHC}=31 \sim 35 \%)\end{array}$ \\
\hline 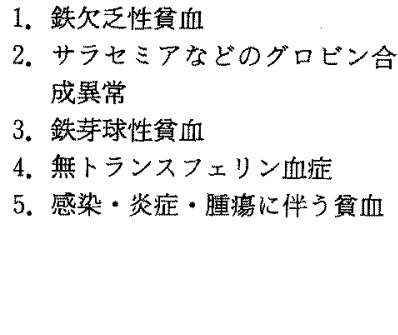 & 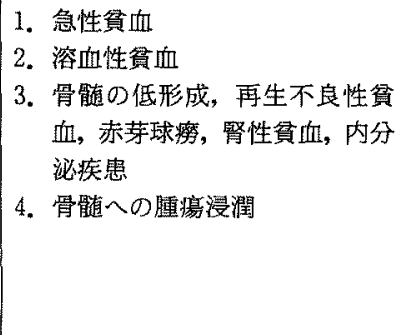 & 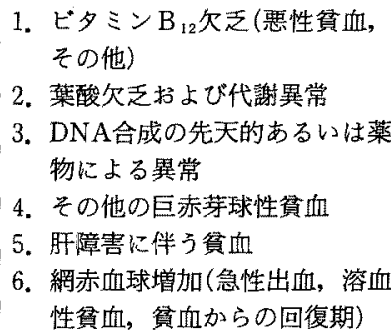 \\
\hline
\end{tabular}

「血清フェリチン」の測定で (図 1)，12ng/mi以下 であれば鉄欠乏性貧血である。鉄芽球性貧血は骨 骾中の環状鉄芽球が全有核細胞の $15 \%$ 以上るこ

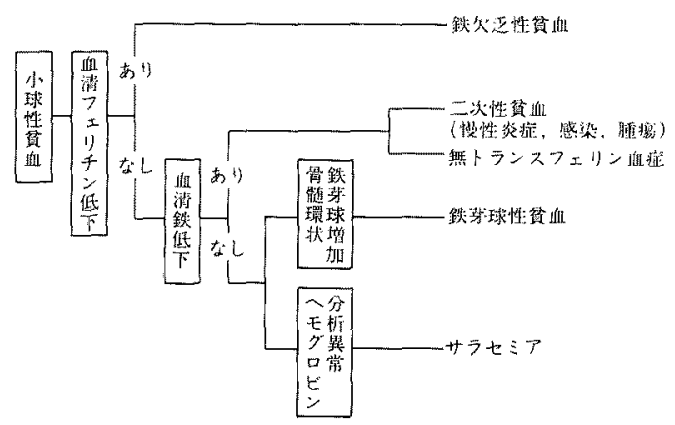

图1.小球性䆬血の鑑别診断とフローチャート
とによって診断される。サセミアの診断にはへ モグロビンの分析が必要である。

(2) 大球性實血 $(\mathrm{MCV} \geqq 101 \mathrm{f})$

MCVが高值を示すような大球性貧血には表 1 と 2 に示すような貧血がある。図 2 のフロー チャートに従って診断を進める。

まず，網赤血球の多寡に注目する，網赤血球は 大きいのでそれが増加すると,MCVは大きくなる ことが多い.この場合は正球性貧血のフロー チャート（図 3 ）に示した網赤血球の増加の場合 と同じ検索を進める.

大球性貧血はビタミン $\mathrm{B}_{12}$ 欠乏と葉酸欠泛がそ の代表であるので,まず血清ビタミン $\mathrm{B}_{12}$ と赤血球 中の葉酸を測定する。それらが低值であればそれ

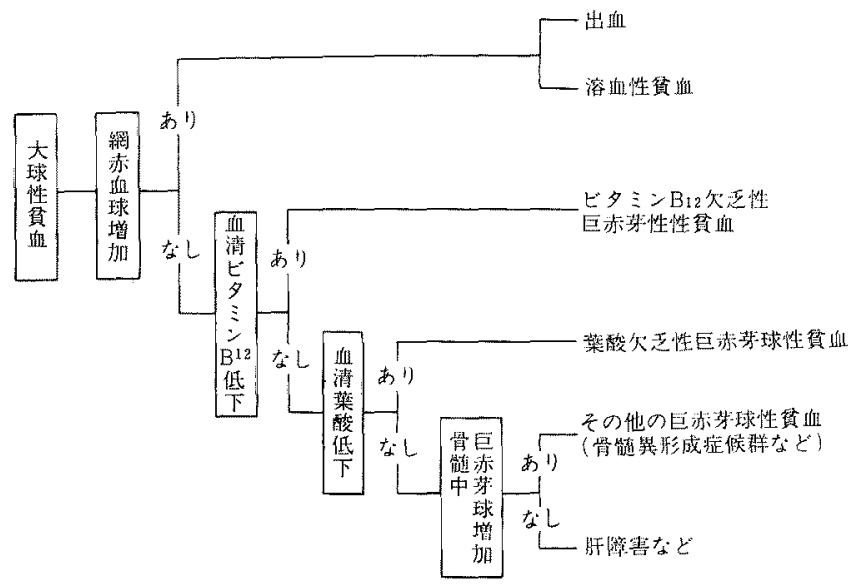

图 2、大球性覚血の鑑別揨断のフローチャート 


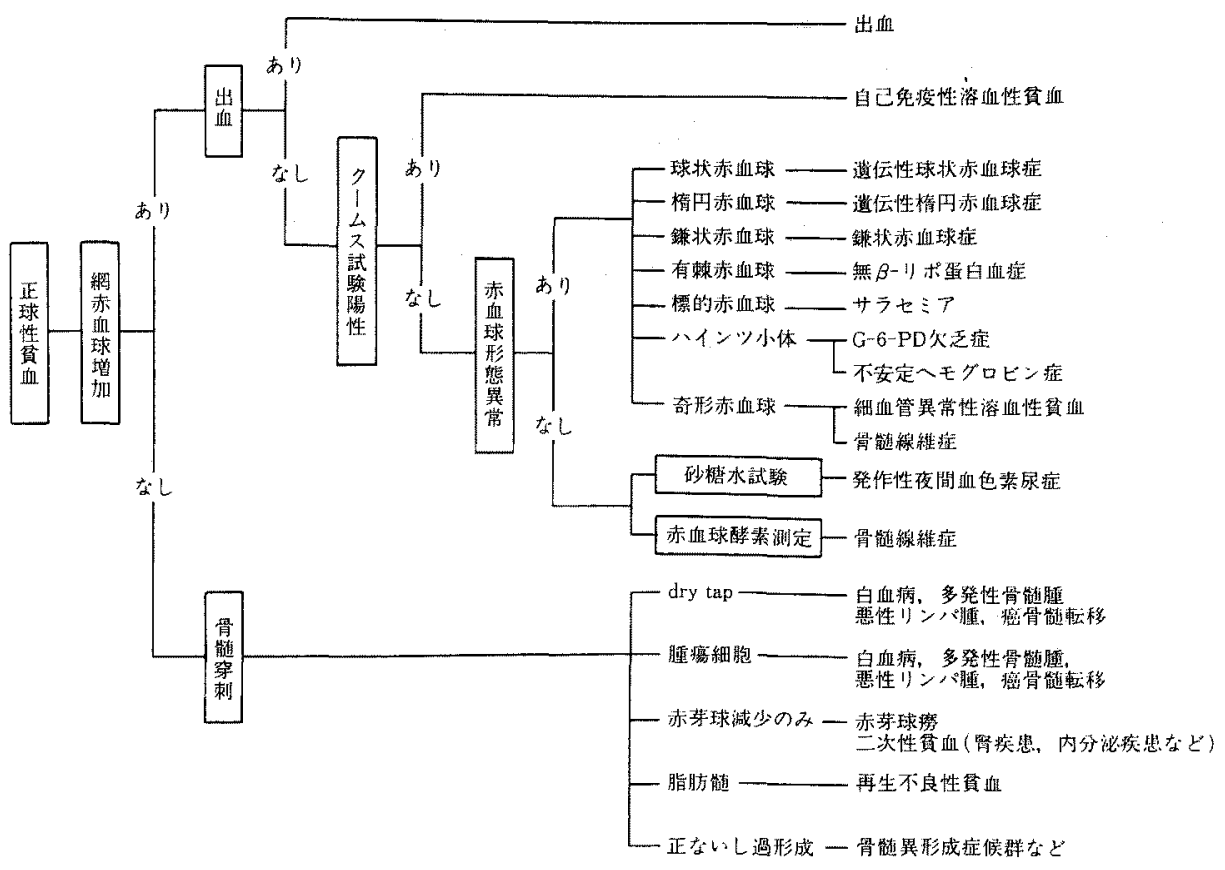

図 3. 正球性貧血の鑑別䛦断のフローチャート

ぞれの欠そと診断する。

血中のビタミン $\mathrm{B}_{12}$ や葉酸測定が低值でなけれ ば骨髄穿刺を行う。骨髄穿刺で巨赤芽球を認める 場合は骨髄異形成症候群 (myelodysplastic syndrome，MDS）が考えられる。もちろんビタミン $\mathrm{B}_{12}$ や葉酸欠乏でも巨赤芽球を認める.巨赤芽球を 認めない場合は肝障害があればそれが原因で，肝 障害がない場合は注意深く経過を観察する。

(3) 正球性實血（MCV $=81 \sim 100 ）$

MCVが正常である正球性貧血は診断が面倒に なり, 図 3 のフローチャートに従い, 網赤血球数 などから診断を進める必要がある。

\section{(2) 網赤血球数}

(1) 網赤血球の多寡の判定

網赤血球の制合や網赤血球の絶対数などでその 多寡を判定する。

網赤血球数㹥通常その割合, つまりパーセント （\%）あるいはプロミレ（\%)で表されている，正 常值は約 $1 \%$ である，さらにその值から，絶対数 を算定してその多寡を判定して欲しい，絶対数と
は赤血球数に網赤血球の割合を掛けて算定した1/ $\mu \mathrm{l}$ 当りの網赤血球数である. その正常值は 4 万 〜 8 万/ $\mu$ である。

\section{(2) 網赤血球が增加している場合の検查}

負血の場合，赤血球の産生過程に異常がなけれ ば，骨髄中の赤芽球が増加し，それに伴って網赤 血球が増加する，その典型例は，溶血と出血であ る.ただし，出血や溶血がなくても，䯣外造血の ある骨髄線維症，脾摘を受けた患者，また貧血か らの回復期の患者でも網赤血球は増加する。

急性出血の場合は出血部位に応じた症状および 所見があるので診断は容易である.

溶血は血清ビリルビン值（間接型）の上昇，血 清ハプトグロブリンの低下からその存在を疑い, 赤血球の寿命の短縮で確認する，溶血が疑われた らまず行う検查はCoombs試験と赤血球形態の観 察である，つまり，溶血性貧血のうちがわが国で 頻度の多い自己免疫性溶血性貧血をCoombs試験 で診断し，遺伝性球状赤血球症を赤血球形態から 診断する。これらに異常がなければ赤血球酵菜の 
測定（赤血球酵素異常による溶血性贫血の診断）， 砂糖水試験（発作性夜間血色素尿症の診断）など を行う。

\section{(3) 網赤血球が増加していない場合}

貧血があっても網赤血球が増加していない場合 は，赤血球産生低下の場合で(表 1)，そのうちの いずれの筫血かを決定しなければならない。その ために骨䯣穿刺を行う.dry tapであれば骨䯣生検 を行う。それでも診断が困難な場合にはフェロカ イネティクスを行う。

\section{a. 骨髄穿刺}

白血病芽球, 骨值腫細胞, リンパ腫細胞, 癌細 胞などの腫瘍細胞が増加していれば，それによる 赤血球産生の抑制が貧血の原因であり, 䛦断は容 易である。

腫腸細胞がなく赤芽球だけが減少していればそ れが筫血の原因である．赤芽球だけが極端に減少 している場合は赤芽球疼であり，全ての血球成分 が滅少し脂肪が多い場合は再生不良性貧血であ る. しかし，再生不良性貿血でも赤芽球が增加し ている場合があり，その場合はMDSとの鑑別が困 難となる。その時は，フエロカイネティクスや骨 髄シンチを行う。

骨䯣中の赤芽球が増加している場合は, 無効造 血が艺進している状態である，その場合に，巨赤 芽球があれば多くの場合大球性筫血となるので表 2 に示すような䝷血を鑑別する．鉄芽球性貧血で は環状鉄芽球が全有核細胞の15\%を超元て增加 し，鉄欠乏性筫血では鉄染色で鉄が染まらない。

\section{b，骨髄生検}

骨髄穿刺がdry tapの時は必ず骨髄生検を行う。 したがって，骨䯣線維症が疑われる時は必須の検 查となる。

\section{2. 賓血の治療}

筫血の治療牥，輸血などの支持療法，薬物療法， 骨髄移植に分けられる。本稿では主に薬物療法に ついて述べる。
表 3，代表的な留血の種類と治療薬

\begin{tabular}{|c|c|}
\hline 䡠血の種類 & 薄 \\
\hline 1. 鉄欠至性貣血 & 鉄剂 \\
\hline $\begin{array}{l}\text { 2. 巨赤芽球性蚠血 } \\
\text { (徳性䝱血な゙) }\end{array}$ & ビタミン $\mathrm{B}_{12}$ ，葉䡆 \\
\hline 3. 鉄芽球性負血 & ビタミン $B_{6}$ \\
\hline 4. 溶血性䆩血 & ステロイド薬, 梚疫抑制薬 \\
\hline 5. 再生不良性䲘血 & $\begin{array}{l}\text { 蛋白同化ステロイド } \\
\text { ステロイド薬 }\end{array}$ \\
\hline 6. 二次性賀血 & $\begin{array}{l}\text { 原疾患の治療 } \\
\text { 餐性血ではリスロポエチン }\end{array}$ \\
\hline
\end{tabular}

\section{1）實血の治療}

貧血の治燎薬は表 3 に挙げるように種類があ る.そのうち造血薬とされるものは鉄郕，エリス ロポエチン，ビタミン $\mathrm{B}_{6}, \mathrm{~B}_{12}$ と葉酸であり，次乏 症以投与する。これ以外堅性實血や再生不良性 貧血に適応がある㔻白同化ホルモンや男性ホルモ ンがある。しかし，腎性㙰血比はリス口ポエチ ンがもっぱら用いられ，蛋白同化ホルモンは用い られていない，その他，溶血性廭血や再生不良性 貧血ではステロイドホルモンなどの免疫抑制薬が 用いられる。

\section{2）鉄欠乏性䆩血の治療}

\section{(1) 鉄剂の投与}

鉄刜の経口投与が鉄欠泛性㕣血治療の根本であ る。鉄として，100 200mg/日投与する. 胃腸症状 がある時は $50 \mathrm{mg} /$ 日にすることもある。

副作用のために，どうしても鉄剤が湌めない場 合法非経口鉄剤を用いる。この他に非経口鉄剂を 用いる場合は経口鉄剤が基礎疾患畐増悪させる場 合（潰場性大腸炎など），あるいは短期間に貧血を 改善させる必要がある場合である。

（2）治療が有効でない場合

鉄剂を投与しても効果のみられない場合があ る.その機序は，(1)鉄欠之性貧血でない場合，(2) 原因（出血など）が持続している場合，(3)患者が 鉄剤を服用していない場合である。

（3）いつまで治療するか

貧血回復後，貯蔵鉄を補うた如に3〜6力月鉄 剂を投与するか，血清フェリチン値が20ng / ml以 上となるまで投与する。 


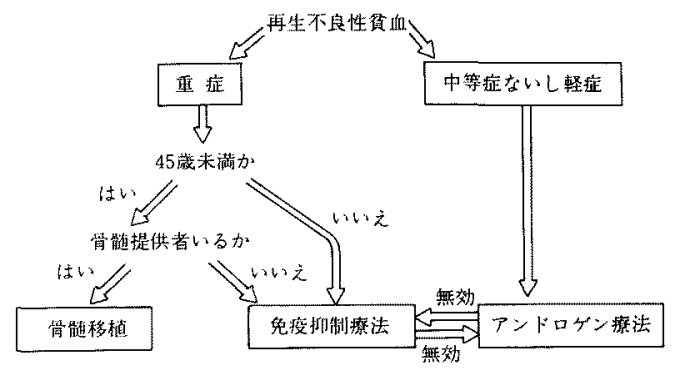

図 4、再生不良性蚠血の治療方針

\section{3）再生不良性實血の治療}

再生不良性督血の治療はその重症度で変わる。 治療方針は図 4 に示すようである。つまり，中等
症か軽症例は蛋白同化ホルモンを用いると 6 力月 ぐらいで，60\%以上の例が改善する．重症例は蛋 白同化ホルモンを用いても生存率は改善しないの で，骨髄移植か免疫抑制療法を行う。免疫抑制療 法としては現在はステロイドパルス療法が行われ ているが，その他シクロスポリン，抗胸腺細胞グ ロブリンや抗リンパ球グロブリンの治験が行われ ている.骨髄移植は45歳未満でかつHLAの合致し た提供者が同胞の中にいる場合に限られる，最近 ドナーバンクが出来, 非血縁者からの移植が行わ れているが，15歳未満の予後は生存率約60\%と良 好であるが，それ以上では約30\%に低下するので 位置付けはまだ明らかでない。 